\title{
Gender Digital Divide in Higher Education: A Study on University of Barisal, Bangladesh
}

\author{
Sumi Rani Saha ${ }^{1}, \mathrm{Md}$. Ohidur Zaman ${ }^{2}$ \\ 1 (Department of Sociology, University of Barisal, Bangladesh) \\ 2(Department of Sociology, University of Barisal, Bangladesh)
}

\begin{abstract}
The descriptive study seeks to explore the digital divide between male and female students of University of Barisal, Bangladesh. The term digital divide is conceptualized in three aspects- access to, usage and ability to use ICTs. A total of 300 students were participated in this study where 150 were male and 150 were female. The field data show that though there are no significant differences in access to and usages of ICTs but there is a notable gender gap in ability of ICTs'usage (Smart Phone and Laptop/desktop). Female students are less efficient in downloading and installing software from internet. Moreover, they are not able to solve the virus related problems and aren't as competent in using MS word, excel and power point as male students are. The main reasons of this gender gap are mental dependency and less learning curiosity of female students in ICT sector.
\end{abstract}

Key Words- Ability, Access, Digital Divide, Gender Gap, Purpose.

\section{INTRODUCTION}

Today's world is changing faster with the rapid spread of new information and communication technologies. But everyone has no equal access and ability to use such technologies that create a new kind of inequality named as the digital divide. The term "digital divide" was first used by Larry Irving, Jr. in the mid1990s, who was the former US Assistant Secretary of Commerce for Telecommunication and Communication, to define the gap between those who can buy the computer hardware and software and who cannot (Boje and Dragulanescu, 2003). Neither people have equal or universal access to ICTs nor they are equally or universally capable of using ICTs. In the study, the term digital divide is conceptualized as disparities in access to and ability in using ICTs. As in post-modern society, information is power, so to take part in this society an individual must have access and learn to use the new and emerging technologies. There can be a variety of digital divides, such as the gender divide, the age divide and the income divide, in a country (Singh, 2010). The main concern of this paper is gender digital divide. The gender digital divide refers to differences between men and women in having access to and ability in using ICTs. We view gender digital divide as unequal access to and ability to use ICTs between men and women. The digital divide has become a dynamic problem with the continuous development of information technologies (Singh, 2015). ICTs access and competency of using ICTs differ by gender. We are interested in finding out the gap between men and women in terms of accessing and competency of using ICTs and how it affects them differently. UNESCO views the gender divide as "one of the most significant inequalities to be amplified by the digital revolution" (Primo, 2003). With the social and economic transition in Bangladesh, the attitude towards gender is also changing. In this circumstance, digital Bangladesh can play a leading role in creating gender sensitive opportunities in various sectors. But women have very limited access to ICTs and they are lagging behind men in using ICTs. Therefore, it is necessary to "engendering ICTs" which is "the process of identifying and removing gender disparities in the access to and use of ICT, as well as that of adapting ICT to the special needs, constraints, and opportunities of women" (World Bank, 2003). One of the targets of Sustainable Development Goals (SDGs) is universal access to internet. All over the world, there are 4 billion people having no access to the internet, almost 2 billion people having no mobile phone and approximately half a billion living in areas where exist no mobile signal (World Bank Report 2016). The participation of women in the Digital Bangladesh enables them to contribute to sustainable development (USAID, 2005). The International Telecommunication Union (ITU) estimated that there are 1 billion internet users in the developed world whereas 2.5 billion internet users are living in the developing world. In 2016, ICT services have become more accessible and affordable, yet more than half of all people are not using the Internet. It is also calculated that $53 \%$ of the world's population is not using the internet by the end of 2016 and in Asia and the Pacific 58.1\% and in Arab States 58.4\% of the population are not using the internet (ITU 2016). 
ICT status of Bangladesh is not satisfactory. The use of computer began in Bangladesh in the 1960s and widely used from the mid-nineties. The country first experienced internet connectivity in 1995, but its rapid use started all over the world in 1990 (Banglapedia, 2006).

An estimation of BBS (2005) was that there is only $1.36 \%$ population of Bangladesh having access to computers. According to Internet World Stats (2016), the total population of Bangladesh is approximately 162, 910,864 and only its $13.2 \%$ of the population use internet, whereas $34.8 \%$ of the population in India, $52.2 \%$ in China, $88.5 \%$ in USA, $92.6 \%$ in UK and $91.1 \%$ in Japan have access to the internet.So, the digital revolution cannot touch the lives of the majority of the people of Bangladesh. The government of Bangladesh started the Digital Bangladesh initiative in 2008 with a view to accelerating the use of ICTs across the Bangladesh by 2020 (Tyers, 2011).In spite of living in the same geographic boundaries and social structures, men and women face different social realities. Women experience inequality in all aspects of their lives. Gender-based inequalities and socio-cultural constraints prevent women from enjoying the benefits of ICTs and contributing to the social and economic advancement of societies on an equal basis with men (World Bank, 2003). Nevertheless, gender stereotypes prevail in society that men are more interested in and more competent at using ICTs. So, the new technologies are the domain for men (Badagliacco, 1990). Besides socio-economic factors (Poverty, illiteracy, lack of computer literacy) socially and culturally constructed gender roles and relationships work as a contributory factor in determining the capability of women and men to take part in the information society on an equal basis (Primo, 2003). In all regions of the world, men have accessed the Internet more as compared to women. The global gender gap in Internet use has increased from $11 \%$ in 2013 to $12 \%$ in 2016 . The highest gender gap prevails in Africa (23\%), whereas the lowest gender gap exists in America (2\%) (ITU, 2016). It is often argued that women have a negative attitude toward ICT (Varank, 2007). Girls tend to like and use computer less (Colley and Comber, 2003), feel less comfortable with computers (Cooper and Weaver 2003) and are less likely to enjoy and feel less involved with computers than boys do (Mucherah, 2003). Cooper and Weaver (2003) found that compared to young men, young women were not sure of their ability with computers. World Internet Project (2009) found gender differences in internet usage in developed countries. 74\% of men and $71 \%$ of women in Australia, 55\% of men and $46 \%$ of women in Czech Republic, $45 \%$ of men and $39 \%$ of women in Hungary, $71 \%$ of men and $64 \%$ of women in Israel, $78 \%$ of men and $77 \%$ of women in New Zealand, 69\% of men and 54\% of women in Singapore, and 68\% of men and 65\% of women in United Kingdom are reported to use internet. Though in Sweden and in the United States an exception is found where the percentage of women who use the internet is higher than the percentage of men but men use the internet more frequently and more intensely.

Existing data from developing countries also confirm that women tend to use ICT less than men. In most Asian countries, though the number of internet users is increasing quickly, women are still lagging behind in terms of internet access and usage (Primo 2003) and in using and ownership of computers (Yelland and Lloyd 2001; Wilson et al. 2003; Pinkard 2005) and they are less likely to interact with computers than men (Mitra et al. 2001). In Africa, women have less access to internet and they are less likely to use internet than men. In Uganda, 31.5 percent of Internet users, in Senegal 12 percent of Internet users and in South Africa 19 percent of Internet users are women, most of them are part of educated urban elite (Primo 2003). Bimber (2000) explored a gap between men and women in terms of accessing and using the Internet because of their differences in socioeconomic status. Chen and Wellman (2004) found that gender affects access to and use of the Internet in a significant way. They revealed that females are less likely than males both to access and to use the Internet. Ono and Zavodny (2003) found that a gap in frequency and intensity of Internet use exists between genders. According to the ITU World Telecommunication (2013), globally, 37\% of all women use the internet, compared with $41 \%$ of all men. The Eurobarometer surveys (2010) on the information society technologies and services showed a gender gap in internet use while percentage of males (49\%) that use Internet daily at home is higher than percentage of females $(40 \%)$ that use internet on a daily basis at home.

Women and men tend to use ICTs differently. There are differences in patterns of use of the internet between men and women. Studies showed that girls use the internet for chatting while boys used the internet for downloading games and music, engaging in online trading, and creating Web pages (Lenhart, Rainie, and Lewis, 2001; Roberts and Foehr, 2004). Men tend to use internet for playing games, watching news and viewing multimedia, while women are more likely to use internet for social networking, online shopping, and email (TNS Digital Survey 2010, cited in Intel 2013: 68). Gender gap in access to ICTs is an arena of sociology as it is one of the means by which women are deprived and underprivileged over men.

We will look at gender differences in both access to and ability of using ICTs as well as how men and women use ICTs differently. The main objectives of the paper are

1. To explore the gender gap in access to ICTs

2. To assess the gap in ability to use ICTs between men and women

3. To find out the gender gap in actual use of ICTS 


\section{MEASUREMENT OF THE CONCEPT 'DIGITAL DIVIDE'}

The most common and widely used indicator of measuring digital divide is internet usage (those who have access to the web and those who do not) (Ragnedda and Muschert, 2013). Besides access to the internet, in this study, other indicators such as having smart phone, personal laptop or desktop computer is used to measure the term digital divide. Unequal access to ICTs is known as the first order digital divide and uneven ability to use ICT is known as the second order digital divide (Jin and Cheong, 2008).There are several forms of digital divides. For the purpose of the study, we use the term 'digital divide' in two ways.

(1) Those who have smart phones, personal laptop or desktop computers and Internet access vs. those who don't

(2) Those who are able to use smart phones, personal laptop or desktop computers and Internet vs. those who don't

First order digital divide, in the study, is conceptualized as a gender gap in access to use ICTs measured by having a smart phone, having a laptop or a desktop computer, access to the internet on mobile phone and laptop or desktop computer and second order digital divide is conceptualized as a gender gap in the ability to use ICTs measured by the ability to web browsing, ability to use Microsoft word (Excel, power point), ability to install programs, ability to download software, ability to open and use an e-mail ID, ability to open and use an account on social networking sites.Besides first and second order digital divide, a gender gap in actual use is measured by the purpose of using ICTs (smart phone, laptop or desktop computer, internet) and amount of time spent using the internet/ amount of time spent online.In this study, ability to use ICTs has been measured by using 15 points binary index. These 15 points are: using smart phone and laptop/desktop without difficulties, ability of internet browsing, ability to open an email account, ability to open a social networking site, ability to install an IMO, WhatsApp and Viber software, ability to install Microsoft Office software, ability to use MS Word, MS Excel, MS power point, ability to install any computer games, computer operating system, ability to download PDF or Power Point files, any software, any entertainment contents (Movie, Drama, Songs etc) from website, ability to remove virus from electronic devices. According to the mentioned points ability in ICT usage has been measured and after that achieved score represents the actual ability of the respondents.

\section{METHODOLOGY}

The study used descriptive research design. University of Barisal, Bangladesh was purposively selected as the study area. For this study we used proportionate stratified sampling technique. From the six faculties (Arts, Science, Bio-science, Social science, Law and Business) of the University of Barisal, six departments (Bangla, Economics, Mathematics, Law, Marketing and Geology and Meaning) were randomly selected. Then from the running semesters of each department, one semester was randomly selected. At first, we collected the lists of the total number of students of the selected semesters from those six departments and then by using systematic sampling technique we selected sample elements in proportion to their actual numbers. Resting on this technique we arrived at a total sample of 300 (150 male and 150 female) students. Using a semi structured questionnaire, face-to-face interview was conducted to collect survey data from the respondents.

\section{DATA PRESENTATION AND RESULT ANALYSIS}

The study focuses on the comparative analysis between male and female students. Therefore, equal number of male and female students was selected to ensure the real scenario. The age range of the participantswasfrom 18 to 22 years old. As the highest number of students exists in Science and Engineering faculty, therefore, most of the participants (34\%) were selected from this faculty. Moreover, $17 \%$ of the students from Arts, $14 \%$ of the students from Social Sciences, $22 \%$ of the students from Law faculty were selected proportionally to represent the real scenario of the ratio of the students in different faculties. At the last stage, participants of the study were selected from different departments in the same process (See Table-01). Among the participants, $47 \%$ of the students were from urban areas, $33 \%$ of the students were from sub-urban areas and $20 \%$ of the students were from rural areas.

Table- 01: Demographic data of the participants.

\begin{tabular}{|l|l|l|}
\hline \multicolumn{1}{|c|}{ Demography } & \multicolumn{1}{|c|}{ Details } & \multicolumn{1}{c|}{ Percentage (\%) } \\
\hline \multirow{2}{*}{ Gender } & Male & 50.0 \\
\cline { 2 - 3 } & Female & 50.0 \\
\hline \multirow{2}{*}{ Age } & 18 & 5.0 \\
\cline { 2 - 3 } & 19 & 21.0 \\
\cline { 2 - 3 } & 20 & 28.0 \\
\hline
\end{tabular}




\begin{tabular}{|l|l|l|}
\hline \multirow{4}{*}{ Faculty } & 21 & 28.0 \\
\cline { 2 - 3 } & 22 & 18.0 \\
\hline \multirow{5}{*}{ Department } & Arts & 17.0 \\
\cline { 2 - 3 } & Science and Engineering & 34.0 \\
\cline { 2 - 3 } & Social Science & 14.0 \\
\cline { 2 - 3 } & Law & 22.0 \\
\cline { 2 - 3 } & Business & 13.0 \\
\hline \multirow{5}{*}{ Location of college } & Bangla & 17.0 \\
\cline { 2 - 3 } & Economics & 14.0 \\
\cline { 2 - 3 } & Mathematics & 22.0 \\
\cline { 2 - 3 } & Law & 22.0 \\
\cline { 2 - 3 } & Geology and Mining & 12.0 \\
\cline { 2 - 3 } & Marketing & 13.0 \\
\cline { 2 - 3 } & Rural & 20.0 \\
\cline { 2 - 3 } & Urban & 33.0 \\
\cline { 2 - 3 } & Sub-urban & \\
\hline
\end{tabular}

Source: Field Data, 2016

\section{Access to ICTs:}

Among all the participants of the study, about $86 \%$ of the male students use smart phone whereas $94 \%$ of the female use smartphone. So, it seems that female students are getting more access to use a smartphone. Not only that, more females, compared to males, have internet access to their smart phones. The students who own a smartphone, among them about $90 \%$ of the male students use internet on their smartphones, whereas $96 \%$ of the female students have internet access on their personal cell phone. In table-02, empirical data show a relatively large gender gap in ownership of personal laptop/desktop because $62 \%$ of male students of the study own a personal laptop/desktop computer whereas only $30 \%$ of the female participants have a personal laptop/desktop computer. In the case of personal laptop/desktop, internet access is not as like as in smartphone. There is a clear gender gap in this aspect. $11 \%$ of the male respondents who own a personal laptop/desktop have internet access on their device but only $05 \%$ of the female students who own a personal laptop/desktop have internet access on their device. Both male and female respondents report that the economic condition of their family is responsible for such gender gap in ownership of personal laptop/desktop.

Table-02: Internet access on personal devices (Smart phone and laptop/desktop)

\begin{tabular}{|l|l|l|}
\hline Access to ICTs & Gender & \\
\hline Smartphone & Male & $86 \%$ \\
& Female & $94 \%$ \\
\hline Internet access on mobile phone & Male & $90 \%$ \\
& Female & $96 \%$ \\
\hline Computer/Laptop & Male & $62 \%$ \\
& Female & $30 \%$ \\
\hline Internet connection on & Male & $11 \%$ \\
computer/laptop & Female & $05 \%$ \\
\hline
\end{tabular}

Source: Field Data, 2016

Now-a-days, internet has become more favorable to young generation for communication. Social networking sites like IMO, WhatsApp, Viber, Facebook, Twitter and Messenger are almost equally used by both male and female participants of the study. Some participants use internet for reading online newspapers but their number is very low. Table 03 shows the real scenario of internet usage of the participants and most of them report that they mainly use internet for the purpose of using social networking sites.

Table-03: Usage of different sites

\begin{tabular}{|l|l|l|}
\hline Access to various internet sites & Male & $46 \%$ \\
& Female & $49 \%$ \\
\hline IMO & Male & $28 \%$ \\
& Female & $24 \%$ \\
\hline WhatsApp & Male & $24 \%$ \\
& Female & $28 \%$ \\
\hline Viber & Male & $15 \%$ \\
\hline
\end{tabular}


Gender Digital Divide in Higher Education: A Study on University of Barisal, Bangladesh

\begin{tabular}{|l|l|l|}
\hline & Female & $21 \%$ \\
\hline Facebook & Male & $48 \%$ \\
& Female & $51 \%$ \\
\hline Twitter & Male & $9 \%$ \\
& Female & $3 \%$ \\
\hline Job sites & Male & $19 \%$ \\
& Female & $19 \%$ \\
\hline Newspaper & Male & $6 \%$ \\
& Female & $5 \%$ \\
\hline Messenger & Male & $15 \%$ \\
& Female & $13 \%$ \\
\hline
\end{tabular}

Source: Field data, 2016

Table-04 shows the purpose of using internet of the respondents on their personal devices. Female participants use internet as a source of entertainment more than the male participants. Compared to male participants, female students show less preference to use e-mail regularly. Moreover, male students are more frequent in downloading different types of internet contents like PDF, Mp3, music videos, drama, movies etc. by using internet. Again female participants show more interest in online shopping as about $42 \%$ of those students who use internet in their personal device buy products from different online shops. In the case of searching any kind of information, male participants are one step ahead from female. About $62 \%$ of the male participants use internet for searching information from different websites whereas $44 \%$ of the female use internet connection for this purpose.

Table 04: Purpose of using Internet on Personal Device

\begin{tabular}{|l|l|l|}
\hline \multicolumn{1}{|c|}{ Purpose of using Internet } & Gender & Percentage \% \\
\hline Using social networking sites & Male & $96 \%$ \\
& Female & $98 \%$ \\
\hline Downloading music and video & Male & $90 \%$ \\
files & Female & $70 \%$ \\
\hline Chatting & Male & $95 \%$ \\
& Female & $96 \%$ \\
\hline E-mail & Male & $75 \%$ \\
& Female & $56 \%$ \\
\hline Shopping & Male & $15 \%$ \\
& Female & $42 \%$ \\
\hline Entertainment & Male & $96 \%$ \\
& Female & $98 \%$ \\
\hline Searching information & Male & $62 \%$ \\
& Female & $44 \%$ \\
\hline
\end{tabular}

Source: Field Data, 2016

Ability in ICT usage:

In the case of internet access and usage, digital divide is not so significant but a significant gender gap is visible in the ability of using ICTs. In the following figure, 15 points ICT ability index shows that male participants are more efficient in usingICT contents in various ways, whereas female participants are able to use social networking and entertainment sites. Male are more capable in using MS office, installing software and games and solving virus related problem than female respondents.

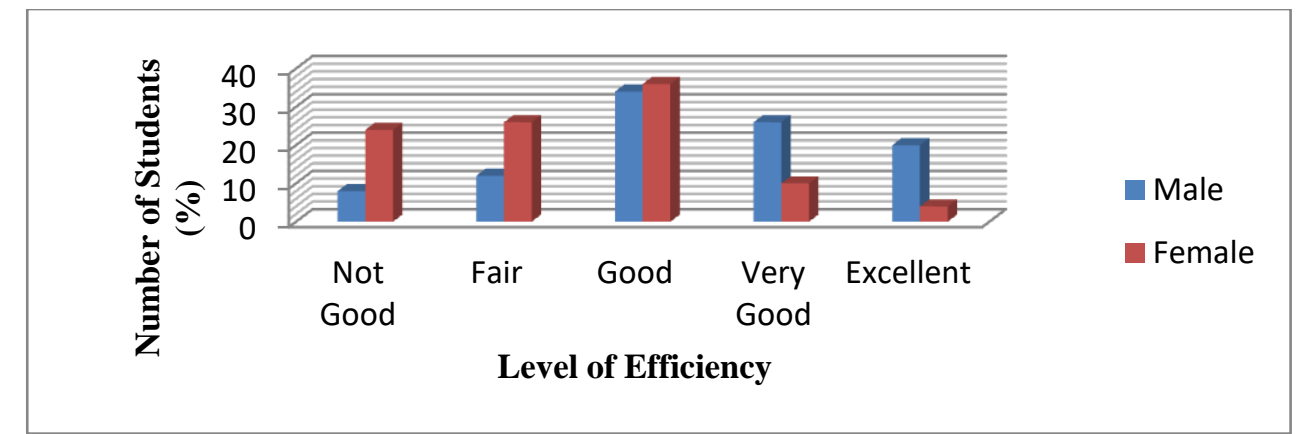

Figure-01: Comparison between male and female students in ability of ICT usage 
Besides, males are more efficient in ICT usage than females because in the higher level of efficiency, the number of males is greater than females. Only $4 \%$ of the females hold "Excellent" whereas $20 \%$ male participants reach that level. Moreover, $26 \%$ of the males, compared to $10 \%$ of the females, hold "Very Good" level. Therefore, you could say that, in our study male students are more efficient in ICT usages than female students. The main causes behind such gender gap are- (1) mental dependency on others, (2) less curiosity in learning (3) more interest in social networking and entertainment sites only and (4) less learning sources.

\section{CONCLUSION}

The comparative study examines whether there are differences in men's and women's access to, usage and ability of using ICTs. After analyzing the empirical data we could conclude that both male and female students have more or less equal access to smart phone and they use internet more for using social networking sites, chatting and entertainment purposes. But there is a significant gender gap in ability of ICT usage. Females are capable of using ICTs for communication purposes but they are less competent in downloading and installing software whereas males show their efficiency in these aspects.

\section{REFERENCES}

[1] Boje, C., and Dragulanescu, N. G., "Digital divide" in Eastern European countries and its social impact, Proc. of the 2003 American Society for Engineering Education Annual Conference and Ex-position, 2003.

[2] Singh, Sumanjeet, Digital Divide in India: Measurement, determinants and policy for addressing the challenges in bridging the digital divide, InternationalJournal of Innovation in the Digital Economy, 1(2), 2010.

[3] Singh, Surya, Assessing the need, challenges and solutions to bridge the divide of digital inequality, Indian Streams Research Journal, 5 (2), 2015.

[4] Primo, N., Gender issues in the information society, UNESCO Publications for the World Summit on the Information Society, Geneva, 2003, 1-83.

[5] World Bank, Engendering ICT: Ensuring gender equality in ICT for development, Gender and Development Group and Global Information and Communication Technologies Department of the World Bank, Washington, DC, 2003, 1-180.

[6] World Bank Report, The World Development Report, 2016, Digital Dividends, 2016.

[7] USAID Bangladesh, Supporting gender and ICTs: opportunities for women in Bangladesh, 2005.

[8] ITU (International telecommunication Union), ITU releases latest global technology development figures, 2016.

[9] Internet World Stats, 2016, http://www.internetlivestats.com/internet-users-by-country/.

[10] Tyers, A., A gender digital divide? Women learning English through ICTs in Bangladesh, 2011.

[11] Badagliacco, J. M., Gender and race differences in computing attitudes and experience, Social Science Computer Review, 8(1), 1990, 42-63.

[12] Varank, I., Effectiveness of Quantitative skills, Qualitative skills, and gender in determining computer skills and attitudes: A causal analysis, The Clearing House, 81(2), 2007, 71-80.

[13] Colley, A., and Comber, C., Age and gender differences in computer use and attitudes among secondary school students: What has changed?,Education Research, 45, 2003, 155-165.

[14] Cooper J., and Weaver K.D., Gender and computers: understanding the digital divide, (Erlbaum Associates, Mahwah, NJ., 2003).

[15] Mucherah, W. M., Dimensions of classroom climate in social studies classrooms where technology is available (middle school students), Dissertation Abstracts International Section A: Humanities and Social Sciences, 60, 2003, 1451.

[16] World Internet Project, World Internet international Report 2009, USC Annenberg School Center for the Digital Future, 2009.

[17] Yelland, N., and Lloyd, M., Virtual kids of the 21st century: Under-standing the children in schools today, Information Technology in Childhood Education Annual, 13, 2001, 175-192.

[18] Wilson, K. R., Wallin, J. S., and Reiser, C., Social stratification and the digital divide, Social Science Computer Review, 21, 2003, 133-143.

[19] Pinkard, N., How the perceived masculinity and/or femininity of software applications influences students' software preferences, Journal of Educational Computing Research, 23, 2005, 57-78.

[20] Mitra, A., Lenzmeier, S., Steffensmeier, T., Avon, R., Qu, N., and Hazen, M., Gender and computer use in an academic institution: Report from a longitudinal study, Journal of Educational Computer Research, $23,2001,67-84$. 
[21] Bimber, B., Measuring the gender gap on the Internet, Social Science Quarterly, 81(3), 2000, 868-876.

[22] Chen, W., and Wellman, B., The global digital divide - Within and between countries, IT\&Society, 1(7), 2004, 39-45.

[23] Ono, H., and Zavodny, M., Gender and the Internet, Social Science Quarterly, 84(1), 2003, 111-121.

[24] ITU, The World in 2013, ICT Facts and Figures, 2013.

[25] Lenhart, A., Lewis, O., and Rainie, L., Teenage life online, Pew Internet \& American Life Project, 2001.

[26] Roberts, D. F., Foehr, U. G., and Foundation, H. J. K. F., Kids and media in America, (Cambridge University Press: UK, 2004).

[27] Intel, Women and the Web: Bridging the Internet gap and creating new global opportunities in low and middle-income countries, Intel Corporation, 2013.

[28] Ragnedda, M., and Muschert, W. G. (Ed.), The digital divide: The internet and social inequality in international perspective, (Routledge : London, 2013.

[29] Jin, J., and Cheong, A. W. H., Measuring digital divide: The exploration in Macao, Observatorio (OBS*) Journal, 6, 2008, 259-272. 